\title{
Memasyarakatkan Bus Rapid Transit Trans Siginjai melalui komunitas dan media digital di Provinsi Jambi
}

\author{
Haryadi dan Moh. Arief Rakhman $(\mathbb{D} *$ \\ Program Studi Ilmu Pemerintahan, Fakultas Ilmu Sosial dan Ilmu Politik, Universitas Jambi \\ * moh.ariefrakhman@unja.ac.id
}

\begin{abstract}
Abstrak. Pada 2018 Trans Siginjai resmi mulai beroperasi di Kota Jambi, dengan jalur menghubungkan Kota Jambi dengan Kabupaten Muaro jambi. Melewati Panjang rute $19 \mathrm{Km}$, melewati 2 kampus besar di Provinsi Jambi. Membuat moda BRT (Bus Rapid Transit) ini memiliki pasar potensial di kalangan masyarakat dari kelompok mahasiswa. Observasi pendahuluan yang dilakukan dan beberapa penelitian menunjukan masa 1 tahun setelah operasionalnya BRT ini menunjukan keadaan yang belum optimal. Solusi yang ditawarkan dari pengabdian yang dilakukan adalah dengan melihat bagaimana sebenarnya sarana transportasi yang dimiliki oleh Provinsi Jambi ini mempunyai banyak potensi tambahan selain sebagai satu-satunya angkutan masal yang ada di trayek ini. Potensi yang bisa dimunculkan oleh BRT TransSiginjai ini adalah Multiple effect edukasi, ekologi, ekonomi. sasaran pengabdian adalah mahasiswa dan masyarakat yang berdomisili di kota Jambi. Metode yang digunakan adalah dengan mengaktivasi komunitas lokal dan optimalisasi penggunaan media digital dengan luaran utama adalah berbagai content multimedia. Setelah dilakukan kegiatan pengabdian belum terjadi perubahan yang siginifikan namun telah terjadi peningkatan awareness di kalangan pengguna media yang di jadikan sasaran pengabdian, yaitu yang berasal dari kalangan pelajar. Dari sisi akademis pengabdian ini juga mencoba membuktikan bahwa sinergisitas komunitas, akademisi dan pihak berwenang mampu memberikan solusi nyata bagi sebuah kota dan masyarakat yg hidup didalamnya.
\end{abstract}

Kata kunci: angkutan masal jambi; bus rapid transit; komunitas; trans siginjai

\begin{abstract}
In 2018 Trans Siginjai officially began operations in the city of Jambi, with a route connecting Jambi City with Muaro Jambi District. Passing the length of the route is $19 \mathrm{Km}$, passing through two large campuses in Jambi Province. Making this BRT (Bus Rapid Transit) mode has a potential market among the community of student groups. Preliminary observations were made and several studies showed that the 1 year period after the operation of the BRT showed a condition that was not optimal. The solution offered from the service done is to see how actually the transport facilities owned by Jambi Province have a lot of additional potential besides being the only mass transportation on this route. The potential that can be raised by the TransTiginjai BRT is Multiple effects of education, ecology, economics. the target of service is students and the community who live in the city of Jambi. The method used is by activating the local community and optimizing the use of digital media with the main output being various multimedia content. After the activities have not been made significant changes have occurred but there has been an increase in awareness among media users who are targeted for service, namely those from students. From the academic side, this service also tries to prove that the synergy of the community, academics and authorities is able to provide a real solution for a city and the people who live in it.
\end{abstract}

Keywords: bus rapid transit; community; jambi mass transportation; trans siginjai

To cite this article: Haryadi, \& M. A. Rakhman. 2019. Memasyarakatkan bus rapid transit trans siginjai melalui komunitas dan media digital di Provinsi Jambi. Unri Conference Series: Community Engagement 1: $310-316$ https://doi.org/10.31258/unricsce.1.310-316

(C) 2019 Authors

Peer-review under responsibility of the organizing committee of Seminar Nasional Pemberdayaan Masyarakat 2019 


\section{PENDAHULUAN}

Pemerintah, melalui Kementerian Perhubungan (Kemenhub) berupaya terus membangun sektor transportasi yang mendukung penyediaan akses bagi masyarakat, mewujudkan keselamatan transportasi, meningkatkan konektivitas nasional, membangun transportasi perkotaan yang aman, nyaman dan terintegrasi. Beragam program tersebut bertujuan untuk memperkuat dan memajukan daerah-daerah dan desa yang berada di pinggiran dan pedalaman Indonesia, meningkatkan pertumbuhan ekonomi serta meningkatkan efesiensi dan efektifitas transportasi nasional. Sebagaimana diamanatkan dalam UU No. 22/2009 tentang LLAJ pasal 139, bahwa pemerintah (pemerintah pusat dan Daerah) wajib menjamin tersedianya angkutan umum untuk jasa angkutan orang dan /atau barang. Baik itu antarkota, antar Provinsi, wilayah Kabupaten/Kota. Di sektor transportasi darat, Kemenhub terus mengembangkan transportasi umum massal perkotaan yang aman, nyaman dan terintegrasi, serta praktis, efesien, ramah lingkungan dan berkeadaban. Bus Rapid Transit (BRT) dan Mass Rapid Transit (MRT) adalah wujud dari penyediaan transportasi perkotaan berkelanjutan yang diharapkan oleh masyarakat. Indonesia juga memiliki inisiatif yang kuat untuk memberikan suatu pengembangan transport yang berkelanjutan.

Bus Rapid Transit (BRT) secara idealnya merupakan sistem transportasi berbasis bus yang berkapasitas dan berkecepatan tinggi, serta memiliki kualitas layanan yang baik dengan biaya yang relative murah. BRT juga mengombinasikan beberapa elemen seperti jalur khusus bus yang pada umumnya berada pada median jalan, penarikan tarif off-board, level boarding, prioritas bus pada persimpangan, dan elemen kualitas layanan lainnya seperti teknologi informasi serta branding yang kuat (2016). Kehadiran BRT di beberapa Kota besar di Indonesia di proyeksikan mampu membawa konsep yang baru dalam perilaku bertransportasi umum yang aman, tertib, dan nyaman. Sarana Transportasi yang di munculkan sepaket, Bus dan halte yang didesain berpintu tinggi, mencoba merubah kebiasaan penumpang yang dulunya menunggu di sembarang tempat berubah, kini bisa tertib naik dan turun di halte, Armada dilengkapi pendingin udara dan keunikannya dibanding dengan layanan bus lain adalah memiliki jalur khusus untuk mempercepat mobilitas (Rudi, 2016).

Ide membangun jaringan BRT, dengan konsep dasar di atas kemudian menular ke kota lain. Mau tidak mau Suksesnya TransJakarta kemudian dijadikan tolok ukur oleh daerah lain untuk mewujudkan jaringan transportasi umum. Permasalahan kemudian muncul pemerintah daerah sepertinya kurang mengkaji aplikasi konsep BRT dengan benar di beberapa daerah. Permasalahan-permasalahan yang kemudian muncul seperti halte-halte bus dibangun di atas trotoar yang sempit, armada yang disediakan sedikit, tidak ada rencana jangka panjang pengembangan, hingga halte yang dibangun asal jadi atau bahkan terbengkalai mulai marak di beberapa kota besar yang mencoba menerapkan system BRT ini. Seolah implementasi BRT di daerah adalah hanya mengubah persoalan kultur bertransportasi umum masyarakat yang biasanya menaikkan dan menurunkan penumpang di sembarang tempat. Kegagalan kota-kota besar di Indonesia untuk menyediakan angkutan umum yang baik, ditandai dengan kondisi angkutan umum yang semakin buruk dengan turunnya kualitas layanan dan penurunan jumlah penumpang angkutan umum. Ditambah lagi kebijakan penyediaan angkutan massal yang cenderung mengesampingkan peran angkutan eksisting (angkot dan bus). Hal ini perlu mendapatkan perhatian khusus dari pemerintah karena tidak bisa dipungkiri bahwa angkutan umum masih dibutuhkan dan masih memiliki potensi untuk dikembangkan.

Bagi pemerintah daerah, terlepas dari permasalahan secara umum kehadiran bantuan bus BRT memiliki arti yang cukup penting. Salah satunya untuk menekan beban biaya transportasi warga kelas menengah ke bawah dan juga permasalahan kemacetan yang di sebagian daerah adalah disebabkan oleh ketidak seimbangan anatara pertumbuhan jumlah kendaraan bermotor dan tidak adanya pertambahan ruas jalan yang membutuhkan pendanaan yang besar. hal ini merupakan salah satu masalah yang terjadi di Kota jambi dengan tingkat kepadatan penduduk yang tertinggi di Provinsi Jambi, Sektor transportasi di Kota Jambi juga turut mengikuti gejala tersebut dimana pertumbuhan kendaraan bermotornya cukup berfluktuasi, yaitu mencapai 1,25\% per tahun. Komposisi terbesar adalah sepeda motor yaitu $87,18 \%$ dari jumlah kendaraan bermotor pada periode 2010-2014 dan tingkat pertumbuhannya mencapai 5\% dalam lima tahun terakhir (Edison, 2018). Rasio jumlah sepeda motor dan penduduk di Kota Jambi mencapai 1:10 pada akhir tahun 2018 tidak sebanding dengan tingkat penambahan ruas jalan dalam kota yang sama sekali tidak bertambah sejak lama. Setiap tahun jumlah kendaraan roda dua bertambah sekitar 1,25\% sedangkan kendaraan roda empat sebesar 8,63\%. Jumlah kendaraan bermotor yang tercatat di Kantor Samsat Kota Jambi diperkirakan sebanyak 55.380 unit pada tahun 2019 (TribunNews, 2019).

Kondisi diatas memunculkan kebutuhan terhadap solusi untuk mengatasi permasalahan yang terjadi, BRT yang kemudian di beri nama TransSiginjai pun kemudian hadir di kota jambi pada 2017, dan beroperasi penuh 
pada awal 2018. Program bantuan pemerintah pusat ini diharapkan menjadi solusi atas permasalahan yang terjadi. Trans Siginjai merupakan bantuan khusus dari pemerintah pusat melalui Kementrian Perhubungan, di serahkan kepada Dinas Perhubungan Provinsi Jambi, yang kemudian dikelola oleh Pihak Djawatan Angkutan Motor Republik Indonesia (Damri). Pada tahap Jambi bakal menerima lima unit mobil. pada tahap awal ini, Dishub Provinsi Jambi telah menyelesaikan pembangunan 19 unit halte dengan tujuh unit halte permanen dan 12 unit halte portabel. Ini merupakan koridor pertama dari rencana empat koridor angkutan Trans Siginjai.. Peluncuran moda transportasi yang masih terbilang baru di provinsi Jambi ini dilakukan pada bulan November 2017, dan disusul dengan masa uji coba sampai Januari 2018, dimana tarif akan di gratiskan bagi masyarakat yang menggunakan Trans siginjai (Antara, 2019).

\section{MASALAH}

Pengoperasian Trans Siginjai resmi dimulai pada akhir 2017. Dinas perhubungan Provinsi Jambi telah mengevaluasi rute yang dilalui oleh angkutan massal Bus Rapid Transit (BRT) Trans Siginjai yang beroperasi di Kota Jambi sebelum adanya penambahan armada. Bahkan pada 2018 setelah melakukan evaluasi pada rute yang memiliki road factor (Beben) tinggi sehingga berpotensi untuk dialihkan, dan itu memungkinkan jika di dukung dengan penambahan armada baru. Dengaan adanya penambahan bus trans siginjai rute akan ditambah dengan pertimbangan utama, melihat potensi besarnya penggunaan bus oleh masyarakat di daerah itu.

Sejak pertama diluncurkan pada November 2017 salah satu yang dirasakan kurang adalah Bus Trans Siginjai dirasakan masih kurang sosialisasi, terutama di daerah yang berdekatan dengan halte pemberhentiannya. Hal ini pun di akui oleh pihak dinas perhubungan Provinsi Jambi. Akibatnya BRT pertama di Provinsi jambi ini Trans Siginjai sunyi dari perbincangan. Kurangnya sosialisasi yang dilakukan oleh pihakpihak terkait terhadap keberadaan moda angkutan ini membuat bagi sebagain kalangan, moda transportasi ini cukup asing, jalur yang belum menyeluruh melayani transportasi di kota jambi, disusul kemudian dengan minimnya bentuk promo bisa menjadi alasan yang menyebabkan hal ini, bagi kalangan mahasiswa Universitas Jambi ataupun UIN Sultan Thaha dan masyarakat yang beraktifitas di Kawasan Jambi Luar kota mungkin waktu 1 tahun sudah mulai akrab dengan moda angkutan ini. Permasalahannya dari wawancara dengan beberapa Informan yang berasal dari pengguna maupun pihak DAMRI sendiri, permasalahan utamanya muncul karena banyaknya penumpang yg lebih didominasi mahasiwa, menyebabkan persepsi baru dikalangan masyarakat, bahwa TransSiginjai adalah angkutan yang "khusus" melayani Mahasiswa dan Pelajar serta kalangan masyarakat yang "berada" saja. Hal ini dibuktikan dengan angka penumpang pertahun yang sama sekali tidak beranjak naik.

\section{METODE}

Pendekatan Studi yang digunakan yaitu studi kasus melalui tahapan (1) mengidentifikasi Potensi Media digitak yang dapat menstimulasi kreativitas sistem jejaring sebagai kekuatan Kolaboratif dan mendukung pihak dpengelola trans siginjai untuk bisa lebih mengenalkan trans Siginjai, (2) mengidentifikasi faktor-faktor yang mempengaruhi munculnya kekuatan kolaboratif dan (3) mengidentifikasi strategi proses dalam menyampaikan gagasan kepada berbagai pihak yang meliputi penilaian proses difusi horisontal, yakni dengan melihat proses penyebaran dan perkembanga gagasan kepada masyarakat dan nantinya penilaian proses difusi vertikal, yakni dengan melihat potensi pengintegrasian ide terhadap kebijakan Pemerintah serta kontribusi yang diberikan Pemerintah terhadap aksi yang nantinya coba dilakukan.

Pengumpulan data dilakukan melalui studi literatur, materi audio visual, observasi dan wawancara kualitatif. Pengambilan sampel kualitatif dilakukan berdasarkan metode sampling purposive atau judgement. Sehingga terpilih pihak-pihak yang akan dilibatkan dalam kegiatan pengabdian ini yaitu Perwakilan Damri, pengurus Komunitas Trans Siginjai, Mahasiswa Fakultas Ilmu Sosial dan Ilmu Politik Universitas Jambi, mahasiswa non Universitas Jambi, dan masyarakat umum.

Solusi yang dihadirkan dengan membantu menggali potensi yang diharapkan bisa membantu moda transportasi ini untuk lebih bisa diterima di para calon penumpang potensialnya, dalam hal ini mereka adalah mahasiswa dan masyarakat umum yang membutuhkan akses terhadap angkutan dengan jalur kota Jambibalpekes di kabupaten Muara Jambi begitu juga sebaliknya.

Untuk itu solusi yang coba di tawarkan adalah memasyarakatkan kembali Trans Siginjai kepada kelompok seperti yang sudah di uraikan keatas. Menurut pengamatan pengguna trans siginjai ini rata-rata mereka yang secara sadar aktif dalam menggunakan media digital, mereka yang terhubung dengan dawai digital nya dalam keseharian. Dari hasil pengamatan ini memunculkan ide bagaimana jika trans siginjai di masayarakatkan 
kembali melalui media tersebut, untuk kelompok ini target minimal adalah munculnya awareness di kalangan mahasiswa tentang alternative transportasi sehari-hari, dengan bonus hal ini juga bisa menyentuh masyarakat umum yang beraktifitas dengan rute yang sama dengan yg dilalui oleh BRT Trans Siginjai.

Kegiatan selanjutnya adalah aktifasi komunitas sebagai langkah awal kolaborasi, Menurut Charles Landry, jaringan dan kreativitas pada hakikatnya saling menguntungkan, karena semakin besar jumlah simpul dalam sebuah sistem semakin besar kapasitas untuk berinovasi (Landry, 2008). Fenomena yang mewakili pernyataan diatas sebetulnya telah marak di Hampir kota-kota besar di Indonesia, dimana sinergisitas diarahkan untuk menjadi solusi atas berbagai macam permasalahan yang ada untuk hal ini sudah muncul bibit komunitas yang dinilai cukup mewakili para pengguna potensial Trans Siginjai, Charming Siginjai merupakan komunitas yang berisikan mahasiswa dengan inisiasi yang berawal dari kampus, bagian dari salah satu tugas matakuliah di fakultas dimana populasi pengguna trans Siginjai berada, kelompok ini akan terlibat aktif dalam mengadakan kegiatan publikasi positif seputar transSiginjai. Landry, mengemukakan bahwa membangun kesadaran akan kebutuhan untuk berjejaring dan berkolaborasi jauh lebih sulit bagi pelaku yang heterogen dengan masingmasing budaya organisasi dan rencana yang dimilikinya. Hal ini akan menjadi tantangan tersendiri, karena pada konsep awalnya komunitas Charming Siginjai yang di bentuk ini akan menjadi melting pot untuk hal-hal yang berbeda tadi dengan kesamaan adalah menginginkan peningkatan kesadaran untuk menjadikan Trans Siginjai sebagai alternative pilihan moda transportasi sehari-hari.

\section{PEMBAHASAN}

\section{Potensi BRT Trans Siginjai}

Trans Siginjai merupakan bantuan khusus dari pemerintah pusat melalui Kementrian Perhubungan, di serahkan kepada Dinas Perhubungan Provinsi Jambi, yang kemudian dikelola oleh Pihak Djawatan Angkutan Motor Republik Indonesia (Damri). Pada tahap Jambi bakal menerima lima unit mobil. pada tahap awal ini, Dishub Provinsi Jambi telah menyelesaikan pembangunan 19 unit halte dengan tujuh unit halte permanen dan 12 unit halte portabel. Ini merupakan koridor pertama dari rencana empat koridor angkutan Trans Siginjai. Peluncuran moda transportasi yang masih terbilang baru di provinsi Jambi ini dilakukan pada bulan November 2017, dan disusul dengan masa uji coba sampai Januari 2018, dimana tarif akan di gratiskan bagi masyarakat yang menggunakan Trans Siginjai.

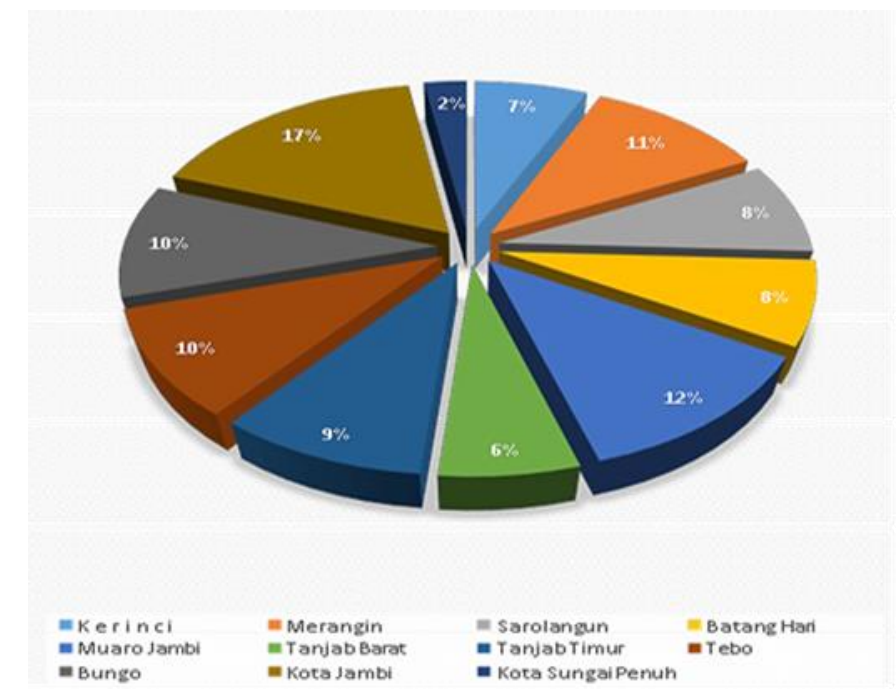

Gambar 1. Distribusi dan Kepadatan Penduduk Menurut Kabupaten/Kota di Provinsi Jambi, 2017

Koridor pertama ini menghubungkan kawasan Telanaipura sebagai pusat pemerintahan Provinsi Jambi dengan daerah Mendalo sebagai kawasan pendidikan yakni Universitas Negeri Jambi dan Universitas Islam Negeri (UIN) Jambi. Dimana menjadi lebih menarik karena halte pertama dari TransSiginjai ini lokasi nya dekat dengan dua tempat strategis lainnya, Rumah Sakit kota Raden Mataher sebagai sarana kesehatan, dan taman anggrek provinsi, sebagai daerah tujuan parawisata kota jambi. Koridor ini memiliki panjang jalur sekitar 30 kilometer, dan 85\% melalui Kawasan padat penduduk. Dengan tarif Rp 3.000 per orang, ada rasa percaya diri yang tinggi dari semua pihak bahwa masyarakat Jambi akan tertarik menggunakan Trans Siginjai. Penempatan koridor pertama yang merupakan jalur paling sibuk di Kota Jambi merupakan point pertama. 
banyaknya mahasiswa beraktivitas dari Jambi menuju kampus kampus besar di daerah Mendalo atau sebaliknya. Di tambah salah satu tujuan Trans Siginjai adalah untuk mengurai kemacetan di Kota Jambi yang semakin hari semakin padat khususnya di jalur ini, dimana kepadatan yang terjadi karena beban jalan yang sangat beragam karena jalur ini menghubungkan kota jambi dan Kabupaten Muara Jambi, dua lokasi di Provinsi Jambi dengan tingkat kepadatan penduduk paling tinggi di Provinsi Jambi.

Kampus dan Mahasiswa sampai saat ini masih merupakan konsumen utama dari BRT ini di bandingkan masyarakat umum, mahasiswa lebih banyak menggunakan moda transportasi ini, hal ini terkonfirmasi dari observasi dan wawancara yang dilakukan dengan pihak DAMRI sebagai pengelola. dari satu kelompok konsumen ini pun diakui belum tergarap dengan maksimal.

Dari berbagai potensi diatas aktifasi komunitas berbasis pengguna yang berasal dari pihak konsumen dimotori oleh para mahasiswa dinilai punya kesempatan besar untuk bisa menaikan minat mahasiswa lainnya khususnya, dan masyarakat pada umumnya (Freska,2012) untuk menggunakan moda transportasi ini. Konektivitas kalangan mahasiswa dengan Media Digital yang cukup tinggi memunculkan potensi untuk positive campaign, publikasi, promosi tersendiri dimana hal ini sepertinya belum optimal dilakukan oleh pihak berwenang, dan berimplikasi dengan belum optimalnya minat masyarakat di dua lokasi strategis tadi untuk menggunakan moda transportasi BRT Trans Siginjai. Hal yang mana beberapa persen dari keseluruhan persentase bisa digarap oleh komunitas Trans Siginjai, dengan konsep Edukasi, Ekologi dan Ekonomi.

\section{Charming Siginjai dan Media Digital}

Berawal dari gerakan yang ingin mengajak masyarakat untuk lebih menggunakan angkutan umum, idenya simple mengurangi kemacetan dan meminimalisir angka kecelakaan di jalan raya terutama rute Kota JambiKampus Universitas Jambi, maka ide ini diwujudkan oleh para mahasiswa prodi Ilmu Politik Fakultas Ilmu Sosial dan Ilmu Politik Universitas Jambi dalam sebuah bentuk Komunitas bernama Charming Siginjai. Ide yang berasal dari tugas mata kuliah Perubahan Sosial dalam topik rekayasa social positif, ini muncul dari keresahan tentang kondisi jalanan yang macet dan bagaimana sebuah solusi yang nyata ada tidak termanfaatkan dengan baik.

Dengan pemikiran sederhana, "lakukan apa yang kita bisa lakukan" dan pemanfaatan media digital komunitas ini kemudian memunculkan beberapa aktifitas online maupun offline.

Tabel 1. Aktivitas Online dan Offline

\begin{tabular}{|c|c|}
\hline Kegiatan Online & Kegiatan Offline \\
\hline Launching Media Sosial & $\begin{array}{l}\text { Minimal } 1 \text { minggu sekali menggunakan } \\
\text { transSiginjai }\end{array}$ \\
\hline $\begin{array}{l}\text { Dokumentasi Video Trip anggota yang di } \\
\text { sebarluaskan dengan multi platform }\end{array}$ & $\begin{array}{l}\text { Mengunjungi Pihak Damri sebagai Pihak } \\
\text { Pengelola. Untuk mendapat masukan dan dukungan } \\
\text { atas kegiatan yang di lakukan }\end{array}$ \\
\hline $\begin{array}{l}\text { Penyebaran tulisan dan content tentang traffic, lalu } \\
\text { lintas, dan E3 concept }\end{array}$ & $\begin{array}{l}\text { Pembagian Flyer informasi keapda lingkungan } \\
\text { kampus tentang rute dan jadwal Trans Siginjai } \\
\text { sekaligus Direct Socialization, dengan tema } \\
\text { mengajak untuk mencoba. }\end{array}$ \\
\hline $\begin{array}{l}\text { Mencoba melakukan koneksi dengan akun-akun } \\
\text { social media stakeholder terkait }\end{array}$ & $\begin{array}{l}\text { Melakukan Street act di halte di seputaran halte- } \\
\text { halte }\end{array}$ \\
\hline \multirow{3}{*}{$\begin{array}{l}\text { Membuat Video pendek terkait TransSiginjai di } \\
\text { channel Youtube dan Variasi series film pendek }\end{array}$} & Kolaborasi dengan Komunitas Lain \\
\hline & $\begin{array}{l}\text { Komunitas Gemar Membaca, komunitas ini } \\
\text { menyediakan buku bacaan gratis di lokasi dekat } \\
\text { dengan Halte Bus. }\end{array}$ \\
\hline & $\begin{array}{l}\text { Komunitas Sekolah Lintas (Komunitas yang peduli } \\
\text { akan keselematan penyebrang jalan terutama di } \\
\text { sekolah-sekolah yang langsung berhadapan dengan } \\
\text { jalan lintas Provinsi) }\end{array}$ \\
\hline
\end{tabular}




\begin{tabular}{ll}
\hline Kegiatan Online & \multicolumn{1}{c}{ Kegiatan Offline } \\
\hline & $\begin{array}{l}\text { Pemasangan Poster Informasi di beberapa Halte } \\
\text { Trans Siginjai }\end{array}$ \\
\hline
\end{tabular}

Kegiatan-kegiatan diatas masih berlangsung, dan ada beberapa yang masih belum bisa dilaksanakan. Dengan berprinsip pada Edukasi, Ekonomi dan Edukasi, kegiatan akan cukup bisa menarik mahasiswa untuk terlibat, sedangkan untuk mengukur secara luas dampaknya bagi masyarakat umum, hal itu akan segera dilakukan dalam tahapan evaluasi kegiatan.

Kegiatan kegiatan diatas juga mendapat tantangan dari segi komunitas, operasional suatu komunitas seperti Trans siginjai Cenderung sangat Cair, tidak ada posisi kepengurusan yang rigid, hanya ada coordinator,sekretaris dan bendahara dan sisanya adalah anggota, yang mana samapai saat ini tingkat keluar masuk nya sangat tinggi. Dari sisi pengorganisasian masih perlu penguatan, disamping permasalahanpermasalahan lainnya seperti Dana, Waktu dan Sumberdaya yang terbatas dalam melaksanakan keberlanjutan kampanye positif ini. Sedangkan dari faktor eksternal terkait dengan permasalahan social dimana absennya angkutan masal yang baik sejak lama memberikan mindset buruk yang terpatri akan angkutan umum di kota Jambi.

Bentuk pelayanan Prima yang kadang juga sulit untuk bisa dirasakan hadir dari pihak pengelola TransSiginjai juga adalah tantangan tersendiri. Waktu keberangkatan yang kadang tidak sesuai dengan yang sudah di Jadwal kan, Kondisi Halte yang terkesan kurang di perhatikan dan penambahan armada yang tak kunjung ter realisasi adalah tantangan tersendiri yang muncul dari Pengelolaan BRT TransSiginjai itu sendiri.

\section{Potensi dan Tantangan Program}

Kegiatan ini mempunyai potensi untuk bisa membangun awareness masyarakat kota Jambi-Muara Jambi dan seputaran jalur yang dilewati oleh rute Bus, dari sisi Ekonomi, tarif tiket yang Rp.3000 dan kenyamanan yang ditawarkan sebenarnya untuk ukuran kota jambi yang sejak lama tidak mempunyai angkutan masal yang representative sudah dirasa cukup bisa menarik banyak peminat. Dari kalangan mahasiswa kebutuhan akan transportasi seperti ini juga sudah mulai muncul, harapannya akan menular kepada masayarakat umum lainnya. Rute yang cukup strategis, koridor yang berdekatan dengan pusat parawisata, sarana Pendidikan, dan Kesehatan memberikan banyak ide yang masih bisa dimunculkan kedepannya. Dari sisi ini tantangan paling utama yang muncul adalah belum terintegrasinya BRT TransSiginjai dengan moda transportasi lainnya. sehingga mobilisasi konsumen bisa saja malah terhambat, walau hal ini mungkin akan segera karena solusi yang datang dari moda transportasi ojek online memberikan pemecahan sementara bagi masalah ini.

Dari sisi Ekologi, menggunakan angkutan masal dan berjalan kaki sedang marak-maraknya di narasikan sebagai suatu gerakan Hijau dan menjadi trend tersendiri di beberapa kalangan, Semakin banyak orang yang peduli dan menerapkan gaya hidup hijau atau green living dalam kehidupan sehari-hari mereka. Hal ini tidak lepas dari makin tumbuhnya kesadaran akan manfaat lingkungan yang sehat bagi kehidupan. Mereka yang cinta lingkungan sadar bahwa pola perilaku manusia merupakan salah satu penyumbang kerusakan lingkungan. Konsep wisata sambil berjalan kaki (walking tour) semakin populer dan diminati ajakan untuk menggunakan sarana transportasi umum seperti TransSiginjai sejalan dengan narasi-narasi yang dibangun tersebut. Narasi beasar mengurangi Polusi akibat penggunaan kendaraan bermotor pribadi yang menyebabkan kerusakan pada alam, dan pas untuk konsumsi mahasiswa karena menjalankan pola hidup hijau belum tentu mahal, hal ini akan kembali ke prinsip narasi pertama yang dibangun oleh komunitas Charming Siginjai, Ekonomi.

Value terakhir yang di narasikan adalah Edukasi, Menggunakan saran transportasi umum sebagai sebuah campaign positif mempunyai nilai edukasi seperti Dengan menggunakan angkutan umum BRT Trans siginjai, secara tidak langsung dapat membantu mendukung program mewujudkan lingkungan bersih dan sehat. Misalnya, program Go Green, Green Living dan lain-lain yang mana ini berkesinambungan dengan point pada paragraph pertama Ekologi. Halte BRT membuat konsumen lebih banyak bergerak, berjalan kaki yang mana aktifitas semacam ini baik untuk kesehatan, selain itu ajakan menggunakan BRT ini pun memberi pesan tersirat dengan menggunakan angkutan umum, tentu saja pengguna akan mengurangi potensi peningkatan polusi udara. BRT Trans Siginjai juga bisa menghidupkan narasi "aman dan Nyaman" setelah 1 tahun beroperasi bus masih cukup terpelihara. Ada nilai Berbagi dan Toleransi dengan menggunakan kendaraan umum ada pelajaran berbagi di kendaraan umum. Berbagi ruang dan kursi. Nilai-nilai Toleransi seperti aturan tidak tertulis wajib memberikan tempat duduk kepada yang lebih membutuhkan yaitu manula, ibu hamil atau yang 
membawa anak kecil dan penyandang disabilitas. Selain itu, program lainnya seperti mengurangi tingkat kemacetan juga menjadi keuntungan dari menggunakan Trans Siginjai. Tak hanya itu, Secara tidak langsung narasi positive campaign yang dibangun adalah secara tidak langsung dapat membantu Pemerintah untuk mengoptimalkan subsidi bahan bakar.

Dengan muatan tiga mind setting diatas, kampanye positif yang dilakukan diharapakan bisa berkelanjutan, apalagi adawacana baru di kota Jambi untuk juga memunculkan moda transportasi BRT yang khusus operasional di kota Jambi. Pemkot Jambi dalam waktu dekat akan menyiapkan angkutan massal berupa Bus Rapid Transit (BRT). BRT Kota Jambi ini nantinya akan menggunakan capsule bus dengan kapasitas 14 seat (Tribun Jambi News, 2019). Hal ini adalah berita menggembirakan, harapan kedepan BRT ini bisa saling terintegrasi satu dengan yang lainnya sehingga menambah daya Tarik tersendiri untuk masyarakat untuk berpindah menggunakan angkutan umum.

\section{KESIMPULAN}

Aktifasi komunitas dalam mengatasi permasalahan-permasalahan social yang ada memang memunculkan hasil yang beragam. Dari beberapa target dan tujuan yang memang ketika di distribusikan kepada komunitas yang di aktifasi, di kemas dalam bentuk yang cukup flexible, bahkan pada awal berbagai aturan dan sisi keorganisasian yang kaku dan rigid coba di hilangkan. Dengan harapan hal ini bisa memunculkan potensi terbaik dari setiap mahasiswa yang ada di dalam komunitas ini. Yang mana hal ini sebetulnya memberikan dampak positif maupun negatif.

Dengan tujuan untuk mengenalkan trans siginjai sebagai moda transportasi masal alternative yang "murah meriah ramah dan smart" dengan nilai-nilai ekologi,edukasi dan ekonomi kepada mahasiswa yang merasa terganggu dengan kemacetan, juga pada umumnya kepada masyarakat yang di awal kemunculannnya mengenal TransSiginjai sebagai Bus Khusus Mahasiswa saja sedikit tercapai, tentu saja ini berkat kolaborasi antar komunitas yang mana masih perlu lebih luas lagi dilakukan untuk kedepannya. Di masa yang akan datang kegiatan ini harus terus dikembangkan lagi, ada banyak hal yang masih bisa dilakukan oleh komunitas ini mengenyampingkan permasalah biaya dan sumberdaya manusianya.

\section{DAFTAR PUSTAKA}

Antara. 2017. Jambi Operasikan Angkutan masal "Trans Siginjai”. https://www.antaranews.com/berita/670964/jambioperasikan-angkutan-massal-trans-siginjai. Diakses pada 1 Juni 2019.

Badan Pusat Statistik Kota Jambi. 2015. Kota Jambi Dalam Angka. Jambi: BPS Kota Jambi.

Badan Pusat Statistik Kota Jambi. 2018. Jambi Dalam Angka. https://jambikota.bps.go.id/publication/2018/08/16/4aa08c71e53d04ad71d0af59/kota-jambi-dalam-angka2018.html. Diakses pada 25 April 2019.

Fitriyana, F. 2012. Peran Komunitas dalam Pengembangan Kota Kreatif, Sudi Kasus:

Identifikasi Kekuatan Kolaboratif. Tesis Program Magister. Institut Teknologi Bandung.

Institute for Transportation and Development Policy (ITDP). 2016. The BRT Standard 2016: The BRT Standart Version GOLD. http://www.itdp.org/?/microsites/brt-standard. Diakses pada 25 Mei 2019.

Landry, C. 2008. Creative city: a toolkit for urban innovation. London: Earthscan.

Mangatur, E. 2018. Analisis Dampak Kemacetan Lalu Lintas Terhadap Pendapatan Masyarakat dan Aksesibilitas Di Kota Jambi. JURNAL PEMBANGUNAN BERKELANJUTAN 1(1): 120-130.

Rudi Asladad. 2015. Semua Provinsi di Indonesia Wajib Punya Sistem BRT http://money.kompas.com/read/2015/07/29/094805826/Semua.Provinsi.di.Indonesia.Wajib.Punya.Sistem.BRT. Diakses pada 20 Mei 2019.

Tribun Jambi News. 201929 ribu lebih kendaraan ikut pemutihan pajak kendaraan dan BBNKB. https://jambi.tribunnews.com/2019/06/27/29-ribu-lebih-kendaraan-ikut-pemutihan-pajak-kendaraan-dan-bbkbdi-samsat-kota-jambi. Diakses pada 1 Juni 2019.

Tribun Jambi News. 2019. BRT Kota Jambi, Saatnya Beralih ke Angkutan Umum. https://jambi.tribunnews.com/2019/04/22/brt-kota-jambi-saatnya-beralih-ke-angkutan-umum. Diakases pada 1 Juli 2019 